\title{
Risk factors for lameness and hock injuries in Holstein herds in China
}

\author{
N. Chapinal, ${ }^{*}$ Y. Liang,† D. M. Weary, ${ }^{*}$ Y. Wang, $\ddagger$ and M. A. G. von Keyserlingk* ${ }^{* 1}$ \\ ${ }^{*}$ Animal Welfare Program, Faculty of Land and Food Systems, University of British Columbia, 2357 Main Mall, Vancouver, V6T 1Z4, Canada \\ †Novus International Inc., 20 Research Park Drive, St. Charles, MO 63304 \\ $\ddagger$ Novus International Trading (Shanghai) Co. Ltd., Room 1001, CITIC Plaza Shenhong, No. 1350 Sichuan Road (N), Hongkou District, Shanghai, \\ China 200080
}

\begin{abstract}
The objective was to investigate the association between herd-level management and facility design and the prevalence of lameness and hock injuries in high-producing dairy cows on commercial freestall farms in China. Housing and management measures, such as stall design, bedding type, and milking routine were collected for the high-producing pen in 34 farms in China. All cows in the pen were gait scored using a 5-point scale, and evaluated for hock injuries using a 3-point scale. Measures associated with the proportion of clinically (score $\geq 3$ ) or severely (score $\geq 4$ ) lame cows, and the proportion of cows having at least a minor hock injury (score $\geq 2$ ) or severe injury (score $=$ 3 ) at the univariable level were submitted to multivariable general linear models. The prevalence [mean \pm SD (range)] of clinical and severe lameness were $31 \pm$ $12(7-51)$ and $10 \pm 6 \%(0-27 \%)$, respectively, and the prevalence of cows with at least a minor hock injury and with severe injuries was $40 \pm 20(6-95)$ and $5 \pm$ $9 \%(0-50 \%)$, respectively. The prevalence of clinical lameness and severe lameness decreased with herd size (estimate $=-0.35 \pm 0.09 \%$ for a 100-cow increase for clinical lameness; estimate $=0.15 \pm 0.06 \%$ for a 100 cow increase for severe lameness). Prevalence increased with barn age $>9$ yr (estimate $=12.73 \pm 4.42 \%$ for clinical lameness; estimate $=5.79 \pm 2.89 \%$ for severe lameness). These 2 variables combined explained $49 \%$ of the variation in clinical lameness and $30 \%$ of the variation in severe lameness. The prevalence of all hock injuries and severe hock injuries decreased with deep bedding (estimate $=-20.90 \pm 5.66 \%$ for all hock injuries; estimate $=-3.65 \pm 1.41 \%$ for severe hock injuries) and increased with barn age $>9 \mathrm{yr}$ (estimate $=16.68$ $\pm 7.17 \%$ for all hock injuries; estimate $=6.95 \pm 1.75 \%$ for severe injuries). These 2 variables explained 52 and $58 \%$ of the variation, respectively. In conclusion, large
\end{abstract}

Received February 28, 2014.

Accepted April 9, 2014.

${ }^{1}$ Corresponding author: nina@mail.ubc.ca variation existed across farms in prevalence of lameness and hock injuries. Changes in housing and management may help control the prevalence of lameness and hock injuries in the emerging dairy industry in China.

Key words: gait, lesion, management, stall design, cow comfort

\section{INTRODUCTION}

China's dairy production has increased sharply since the mid 1990s in response to growing internal demand for dairy products, situating China among the world's top milk producers (Zhou et al., 2002; Fuller et al., 2006; Ma et al., 2012). This growth is the result of an increase in both the national dairy herd (composed of mostly Holstein cows; DAC, 2008) and milk production per cow. The growth within the Chinese dairy industry has resulted in major structural changes, including an increase in herd size and decline in the number of very small farms (milking $\leq 10$ cows; Fuller et al., 2006; Ma et al., 2012).

The growth and intensification of China's dairy industry poses management challenges; in part, because practices implemented on larger farms often differ from traditional practices. Freestall barns are becoming common, but work from North America (Espejo and Endres, 2007; Barrientos et al., 2013; Chapinal et al., 2013) and Europe (Dippel et al., 2009; Kielland et al., 2009; Barker et al., 2010) has shown that the prevalence of lameness and leg injuries can be high in poorly managed freestall barns. Recently, Wu et al. (2012) identified lameness as the most common reason for culling in one 3,000-cow herd, suggesting that lameness is likely a major concern in China. Measuring herd prevalence of lameness and leg injuries and determining the associated risk factors may help to develop strategies for improving the health and welfare of cows in China's emerging dairy industry. The objective of the current study was to investigate the association between herd-level management and facility design and the prevalence of lameness and hock injuries in high-producing dairy cows on commercial freestall farms in China. 


\section{MATERIALS AND METHODS}

\section{Farm Selection and Visits}

A total of 34 farms in China (13 farms in the Huabei region and 21 in the Huadong region) were selected within the C.O.W.S. program, a partnership between The University of British Columbia and Novus International Inc. (http://www.novusint.com/services/cows), for this cross-sectional study. Novus sales representatives $(\mathrm{n}=3)$ and distributors $(\mathrm{n}=3)$ were asked to select farms among their list of clients, considering the following inclusion criteria: Holstein cows, freestall housing, provision of a TMR, and milking $\geq 150$ cows. All methods used to collect data were approved by the University of British Columbia Animal Care Committee (Vancouver, BC, Canada), which follows the standards outlined by the Canadian Council on Animal Care (CCAC, 2009).

Farms were visited from September to December 2012. The same 2 trained observers performed all animal- and facility-based measures on all farms. One group of high-producing and primarily multiparous cows was assessed on each farm; this "high" group was identified by the producer. The group size (mean \pm $\mathrm{SD})$ was $111 \pm 68$ cows, ranging from 38 to 303 cows. Based on 14 farms with available data, the mean \pm standard deviation (range) parity, DIM, and daily milk production $(\mathrm{kg} / \mathrm{d})$ of the assessment group was $2.4 \pm$ 0.4 (1.9-3.1), $110 \pm 75$ (29-272) DIM, and $34.7 \pm 6.6$ (20.9-45.6) kg/d, respectively.

\section{Lameness Assessment}

All cows housed in the assessment group were gait scored as they exited the parlor using a 5-point numerical rating system (NRS), where $1=$ sound and $5=$ severely lame (Flower and Weary, 2006; Chapinal et al., 2009). Cows with NRS $\geq 3$ were considered clinically lame and cows with NRS $\geq 4$ were considered severely lame. The percentage of clinically and severely lame cows was calculated for each farm.

\section{Hock Assessment}

All cows housed in the assessment group were scored during milking for hock condition (lateral surface of the tarsal joint) on a 3-point scoring system, where $1=$ healthy hock without alopecia, $2=$ bald area on the hock without evident swelling, and $3=$ evidently swollen or severe injury, or both, according to the Hock Assessment Chart for Cattle developed by the Cornell Cooperative Extension (http://www.ansci.cornell.edu/ prodairy/pdf/hockscore.pdf). Only 1 limb per animal was considered for this assessment due to the difficulty in examining the opposite side in some type of parlors (i.e., herringbone parlor). Efforts were made to systematically score the right hock of half of the animals and the left hock of the other half within each assessment group; the only exception was on farms using rotary parlors $(\mathrm{n}=7)$, where the same leg for all cows was assessed. The percentage of cows with at least a minor injury (score $\geq 2$ ), and the percentage of cows with a severe injury ( score $=3$ ) was calculated for each farm.

\section{Management and Facility Design Measures}

Management and facility design measures (Table 1) considering potential risk factors for lameness and hock injuries were collected using direct observation of environment and management, an interview with the herd manager during the farm visit, bedding samples, and compilation of herd records, when available.

General Management. General herd and management factors included herd size (obtained from farm records, when available, or estimated by the herd manager), barn age (estimated by the herd manager), and access to an exercise corral (time of day and season and stage of lactation when the corral was available varied across farms).

Pen Design and Management. Thirty of the assessment pens had concrete floors, so flooring was not included as a potential risk factor due to lack of variability. Manure in the pen was removed either continuously or at a high frequency using an automatic scraper, or just a few times per day using other methods, such as a shovel or a skid steer. Therefore, a dichotomous variable was created for the presence of an automatic scraper as opposed to other methods with lower frequency of manure removal. Stall stocking density was calculated as the number of cows per available stalls (i.e., stalls with visible barriers preventing cows from lying down were excluded) multiplied by 100 . The farm with the highest value for stocking density $(160 \%)$ was considered an outlier and this value was not considered in the analysis. The next highest value of stocking density was $110 \%$.

Stall Design. Stall dimensions were measured on 6 stalls per assessment pen, and included width, neck rail position (calculated as the horizontal distance between the rear edge of the neck rail and the rear curb), and neck rail height from bedding. Stalls were systematically selected based on the number and the uniformity of stalls within the pen. For example, if the pen had 100 head-to-head double-row stalls, every 16th stall was selected or if the pen had 50 head-to-head double-row stalls and 50 single-row stalls, every 16th single row was selected and every 16th double row was selected. 
Table 1. Herd-level predictors of interest considered in the univariable analysis ${ }^{1}$

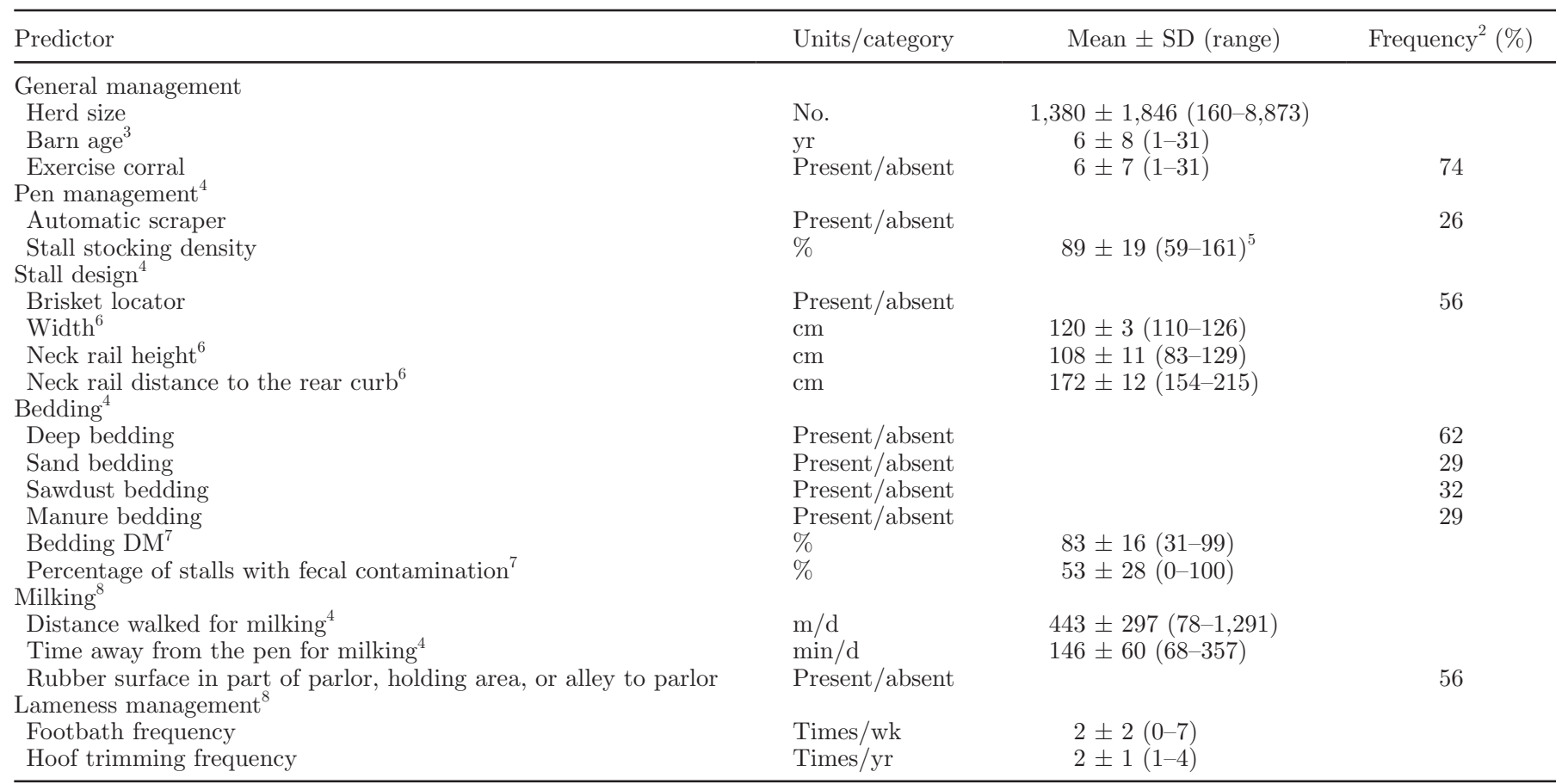

${ }^{1}$ Units, mean $\pm \mathrm{SD}$, and range are shown for continuous predictors, and categories and frequencies for categorical predictors.

${ }^{2}$ Percentage of farms where the predictor was present.

${ }^{3}$ Dichotomized into $<9$ or $\geq 9$ yr for the analysis.

${ }^{4}$ In high-producing assessment group.

${ }^{5}$ The farm with a $160 \%$ stocking density was an outlier and was not considered in the analysis. The next highest value was $110 \%$.

${ }^{6} \mathrm{n}=6$ stalls $/$ pen.

${ }^{7} \mathrm{n}=10$ stalls/pen, assessed before the morning milking.

${ }^{8}$ Predictors considered in the risk factor analysis for clinical and severe lameness only.

These measurements were averaged to obtain 1 value per farm. Total stall length and stall length from the rear curb to the brisket locator were also measured. The effective stall length for the cow depends on factors that affect the lunge space, such as the presence and position of the brisket locator, and whether the stalls are in a single row (facing a wall or feed alley) or double row (2 stalls, head to head). Due to the large variability in those factors, both within and between farms, it was not possible to develop a stall-length definition that was consistent across farms. Therefore, stall length was not considered in the analysis. Presence of brisket locator was recorded.

Bedding Type and Quality. The stall base and type of bedding used in the assessment pen was recorded. Dichotomous variables were created for deep bedding (the stall base was not exposed by digging at least $10 \mathrm{~cm}$ into the bedding as opposed to smaller amounts of bedding placed onto concrete, mattresses, or rubber mats) and the most frequent bedding materials, namely manure, sand, and sawdust. Bedding samples were col- lected from 10 stalls distributed throughout the pen (if the pen had 100 stalls, every 10th stall was sampled). Samples of approximately $50 \mathrm{~mL}$ were taken from the back one-third of each stall and pooled together into 1 sample per farm. The percentage DM of the bedding was analyzed at the National Animal Nutrition Laboratory at China Agricultural University (Beijing, China) and the Ruminant Nutrition Laboratory at Zhejiang University (Hangzhou, China). The same stalls were also assessed for fecal contamination and classified as either clean and dry or as containing fecal contamination. The percentage of stalls containing fecal contamination was calculated for each farm.

Milking. The daily total time cows were away from the pen for milking was calculated as the time ( $\min$ ) since the first cow left the assessment pen until the moment when the last cow returned to the pen (assessed during 1 milking), multiplied by milking frequency per day. The distance between the assessment pen and the milking parlor was recorded and multiplied by 2 times the milking frequency to calculate the total mandatory 
Table 2. Univariable associations of the prevalence of clinical and severe lameness with herd-level factors in 34 freestall herds in China $^{1}$

\begin{tabular}{lcccc}
\hline Variable & $\begin{array}{c}\text { Parameter } \\
\text { estimate }\end{array}$ & $\mathrm{SE}$ & $\mathrm{R}^{2}$ & $P$-value \\
\hline Clinical lameness (\%) & & & & \\
Herd size (100-cow increase) & $\mathbf{0 . 3 7}$ & $\mathbf{0 . 0 9}$ & $\mathbf{0 . 3 3}$ & $<\mathbf{0 . 0 0 1}$ \\
Access to exercise corral & 14.74 & 3.84 & 0.31 & 0.001 \\
Barn age $\geq \mathbf{9}$ yr & $\mathbf{1 3 . 7 0}$ & $\mathbf{4 . 8 9}$ & $\mathbf{0 . 2 0}$ & $\mathbf{0 . 0 1}$ \\
Severe lameness (\%) & 6.78 & 2.29 & 0.22 & 0.01 \\
Access to exercise corral & $\mathbf{- 0 . 1 5}$ & $\mathbf{0 . 0 6}$ & $\mathbf{0 . 1 8}$ & $\mathbf{0 . 0 1}$ \\
Herd size (100-cow increase) & $\mathbf{6 . 1 3}$ & $\mathbf{2 . 8 3}$ & $\mathbf{0 . 1 3}$ & $\mathbf{0 . 0 4}$ \\
Barn age $\geq \mathbf{9}$ yr & &
\end{tabular}

${ }^{1}$ Only associations at $P \leq 0.05$ are shown. Herd-level factors are sorted separately for clinical and severe lameness by descending $\mathrm{R}^{2}$. Bold denotes variables that remained in the final model.

distance that cows walked per day due to milking. The presence of rubber flooring in at least part of the parlor, holding area, or alley to parlor was recorded.

Hoof Management. The number of times each cow was hoof trimmed per year and the frequency of footbath per week was recorded. The type of the footbath used was not recorded.

\section{Data Analysis}

Statistical analyses were performed with SAS (version 9.3; SAS Institute Inc., Cary, NC), considering the herd as the experimental unit. The 4 outcomes of interest were the prevalence of high-producing cows with clinical lameness, severe lameness, at least a minor hock injury, and a severe hock injury. Univariable analyses (PROC GLM) were first performed to assess the association between the outcome variables and each of the predictors (Table 2). Only categorical predictors with at least 6 farms per category were considered. When linearity between continuous predictors and outcome variables was assessed, the predictor barn age did not show a linear relationship. The 5 quintiles were used as cut points to dichotomize barn age, and the cut point yielding the largest coefficient of determination was chosen $(<9$ or $\geq 9$ yr). Predictors with a univariable association of $P<0.10$ were submitted to a multivariable general linear model (PROC GLM). However, none of the predictors associated at $0.05<P<0.10$ remained in the final model and, therefore, will not be discussed further. Correlations between the predictors were calculated to avoid submitting highly correlated variables $(|\mathrm{r}|>0.70)$ to the same model. When 2 predictors were highly correlated, one predictor was selected based on its coefficient of determination in the univariable model and the hypothesized casual model (Dohoo et al., 2009). Variance inflation factors were calculated after each model to confirm lack of multicollinearity. Models were built by manual stepwise selection. First, predictors were removed from the final model if $P>$
0.05 through manual backward elimination, provided that the removal of a variable did not change the parameter estimate of any of the remaining predictors by $\geq 30 \%$ (Dohoo et al., 2009). Eliminated predictors were then individually reentered into the model and retained if $P \leq 0.05$. Two-way interactions between the predictors that remained in the final model were tested, but none was retained $(P>0.05$ in all cases). Residuals were examined after each model to verify normality and homogeneity of variance. Outliers, high leverage points and observations with an undue influence in the model were examined using residuals, leverage values, and Cook's distances.

\section{RESULTS}

Large variation existed across farms in the facility design and management practices (Table 1) as well as in the prevalence of lameness and hock injuries. The prevalence $[$ (mean $\pm \mathrm{SD}$ (range)] of clinical and severe lameness were $31 \pm 12(7-51)$ and $10 \pm 6 \%(0-27 \%)$, respectively. The overall prevalence of cows with hock injuries was $40 \pm 20 \%$ (6-95\%), and prevalence of cows with severe hock injuries was $5 \pm 9 \%(0-50 \%)$.

\section{Herd-Level Risk Factors for Lameness}

At the univariable level (Table 2), the prevalence of clinical and severe lameness decreased with increasing herd size, and increased with access to an exercise corral and barn age $\geq 9$ yr. Access to an exercise corral was correlated with herd size $(\mathrm{r}=-0.56 ; P=0.001)$ and did not remain in the final models controlling for herd size (i.e., the association between access to an exercise corral and lameness was confounded by herd size). The final model for clinical lameness included herd size (estimate $=-0.35 \pm 0.09 \%$ for a 100-cow increase; $P<$ 0.001 ) and barn age $\geq 9$ yr (estimate $=12.73 \pm 4.42 \%$; $P=0.01)$, and explained $49 \%$ of the variation $\left(\mathrm{R}^{2}=\right.$ $0.49)$. The final model for severe lameness included herd 
size (estimate $=0.15 \pm 0.06 \%$ for a 100-cow increase; $P$ $=0.02)$ and barn age $\geq 9 \mathrm{yr}$ (estimate $=5.79 \pm 2.89 \%$; $P<0.01)$, and explained $30 \%$ of the variation $\left(\mathrm{R}^{2}=\right.$ $0.30)$.

\section{Herd-Level Risk Factors for Hock Injuries}

The farm with the highest prevalence of severe hock injuries $(50 \%)$ was not included in the models for severe hock injuries because it was an outlier and an influential observation (large residuals and Cook's distance) in most of the univariable models and the multivariable model for that outcome variable. At the univariable level (Table 3), the prevalence of hock injuries (overall and severe hock injuries) decreased with the use of deep bedding and increased with barn age $\geq 9 \mathrm{yr}$ and the use of sawdust bedding. The use of deep bedding and sawdust bedding were negatively correlated $(\mathrm{r}=-0.70$; $P<0.001)$; most of the deep-bedded stalls used manure or sand, and only 1 farm used sawdust in deep beds. Only deep bedding was submitted to the final models. The final model for the overall prevalence of hock injuries included deep bedding (estimate $=-20.90 \pm$ $5.66 \% ; P=0.001$ ) and barn age $\geq 9$ yr (estimate $=$ $16.68 \pm 7.17 \% ; P=0.03)$, and explained $52 \%$ of the variation $\left(\mathrm{R}^{2}=0.52\right)$. The final model for the prevalence of severe hock injuries included deep bedding (estimate $=-3.65 \pm 1.41 \% ; P=0.02)$ and barn age $\geq 9 \mathrm{yr}$ (estimate $=6.95 \pm 1.75 \% ; P<0.001$ ), and explained $58 \%$ of the variation $\left(\mathrm{R}^{2}=0.58\right)$.

\section{DISCUSSION}

\section{Prevalence of Lameness and Hock Injuries}

The prevalence of lameness and hock injuries varied substantially across farms, as expected, based on the variation observed in the management practices and facility design. The prevalence of clinical lameness was similar to the range of 25 to $31 \%$ reported for Minneso- ta, California, and British Columbia and lower than the prevalence of $55 \%$ reported for the northeastern United States in studies that also targeted the high-producing group in freestall Holstein herds (Espejo et al., 2006; von Keyserlingk et al., 2012). The prevalence of severe lameness was similar to the range of 4 to $8 \%$ reported for those regions. In agreement with von Keyserlingk et al. (2012), the overall prevalence of hock injuries was higher than the prevalence of clinical lameness, and it was similar to the prevalence reported in British Columbia $(42 \%)$ but lower than that reported in California (56\%) and in the northeastern United States (81\%) for high-producing freestall-housed cows. The prevalence of severe hock injuries was within the range of 2 to $5 \%$ reported for those regions.

Herd size was negatively associated with clinical and severe lameness. Some earlier studies in Europe reported increased risk of lameness in larger herds (Arkins, 1981; Alban, 1995; Whitaker et al., 2000). Alban (1995) suggested that, as a consequence of more mechanization and less labor in large herds, farmers spent less time observing their cows, limiting the opportunity to identify and treat lame cows. However, these earlier European studies focused mostly on small herds, with diverse use of technology, mechanization, and labor. More recent studies in North America have sampled larger herds (in a similar range to the current study), for which differences in mechanization and technology were less likely to be related to herd size, and found either no effect (Espejo and Endres, 2007; Barker et al., 2010) or (similar to the current study) a negative relationship between herd size and lameness (Chapinal et al., 2013). We suggest that the positive effects of larger herds in the current study are due to more professionalized management on larger farms, including the availability of staff specifically responsible for lameness and hoof health.

Barn age was associated with increased lameness and hock injuries. Commonalities among older barns likely

Table 3. Univariable associations of the prevalence of cows with at least one minor hock injury (all hock injuries) and a severe hock injury with herd-level factors in freestall herds in China ( $\mathrm{n}=34$ and 33 for all hock injuries and severe hock injuries, respectively $)^{1}$

\begin{tabular}{lcccc}
\hline Variable & $\begin{array}{c}\text { Parameter } \\
\text { estimate }\end{array}$ & $\mathrm{SE}$ & $\mathrm{R}^{2}$ & $P$-value \\
\hline All hock injuries (\%) & & & & \\
Deep bedding & $\mathbf{2 7 . 0 6}$ & $\mathbf{5 . 3 9}$ & $\mathbf{0 . 4 4}$ & $<\mathbf{0 . 0 0 1}$ \\
Barn age $\geq \mathbf{9}$ yr & $\mathbf{2 7 . 9 0}$ & $\mathbf{7 . 7 1}$ & $\mathbf{0 . 3 0}$ & $\mathbf{0 . 0 0 1}$ \\
Sawdust bedding & 22.53 & 6.58 & 0.27 & 0.002 \\
Severe hock injuries (\%) & & & & \\
Barn age $\geq \mathbf{9}$ yr & $\mathbf{9 . 0 1}$ & $\mathbf{1 . 7 0}$ & $\mathbf{0 . 4 8}$ & $<\mathbf{0 . 0 0 1}$ \\
Deep bedding & $-\mathbf{6 . 2 0}$ & $\mathbf{1 . 5 0}$ & $\mathbf{0 . 3 6}$ & $<\mathbf{0 . 0 0 1}$ \\
Sawdust bedding & 5.97 & 1.71 & 0.29 & 0.002 \\
\hline
\end{tabular}

${ }^{1}$ Only associations at $P \leq 0.05$ are shown. Herd-level factors are sorted separately for clinical and severe lameness by descending $R^{2}$. Bold denotes variables that remained in the final model. 
exist, such as smaller or damaged stalls, harder or more abrasive stall bases, less effective manure drainage, or poorer floor quality, which can damage the hoof directly (i.e., the standing surface is wet and abrasive) or indirectly (i.e., the stalls are uncomfortable, causing cows to stand for longer periods on hard, wet floors; Cook and Nordlund, 2009). Uncomfortable stalls are also known to increase the risk of hock injuries (Weary and Taszkun, 2000; Fulwider et al., 2007; Barrientos et al., 2013), likely through abrasion or prolonged pressure on bony prominences while cows lie down, or through collision with the stall partitions or the lying surface in the course of lying down and standing up. Similar to the effect of herd size, further research should aim to identify specific risk factors that directly affect leg health.

In agreement with the previous literature (Lombard et al., 2010; Barrientos et al., 2013; Brenninkmeyer et al., 2013), the use of deep bedding decreased prevalence of hock lesions. When animals lie down, the soft tissue of the joint is compressed against the lying surface. More bedding adds cushioning and avoids the contact of the skin with abrasive stall bases, thereby preventing hair loss and skin breakage. Deep-bedded stalls were typically bedded with sand or dried manure. The use of sawdust bedding, typically in scant amounts on top of mats, mattresses, and concrete lying surfaces, was positively associated with hock injuries. As in other studies (Weary and Taszkun, 2000; Fulwider et al., 2007; Barrientos et al., 2013), we could not tease apart confounding between bedding quantity and material. The prevalence of hock injuries was very similar for deep-bedded barns with sand and manure (overall prevalence: 31 vs. $28 \%$ for manure and sand bedding, respectively; prevalence of severe hock injuries: $2 \%$ in both cases) despite the different properties of these 2 materials (i.e., inorganic vs. organic, different water content, and so on). Previous studies have found a lower prevalence of hock injuries on farms using deepbedded sand (Weary and Taszkun, 2000; Fulwider et al., 2007; Barrientos et al., 2013), manure (Husfeldt and Endres, 2012), deep layers of sawdust (e.g., $\geq 4$ $\mathrm{cm}$ of sawdust compared with mattresses with $\approx 1 \mathrm{~cm}$ of primarily sawdust; Weary and Taszkun, 2000), and straw [e.g., straw yards (Haskell et al., 2006; Rutherford et al., 2008); deep layers of straw or straw-dung (Brenninkmeyer et al., 2013)]. These results indicate that deep bedding has a protective effect when paired with well-managed bedding materials. Sand might provide additional benefits; for example, it is not easily scraped aside to reveal hard or abrasive surfaces (Weary and Taszkun, 2000), it provides a poor medium for bacterial growth (Zdanowicz et al., 2004; van Gastelen et al., 2011), and it drains well (Zdanowicz et al., 2004). These properties might help prevent or heal hock injuries (Norring et al., 2008; Lombard et al., 2010), particularly on farms where stall maintenance is a challenge. We recommend sand bedding or the use of deep, dry, organic bedding if sand is unavailable.

\section{Study Design}

This was a cross-sectional study (risk factors and the outcome of interest were measured at the same time), making it impossible to draw strong conclusions about causality. This shortcoming applies mostly to management practices that are easy to modify and that are associated with increased health problems (certain practices can increase health problems but increased health problems can also lead to certain practices) and less with practices associated with improvements in health or risk factors that are less flexible, such as the majority of facility and management predictors considered in this study.

Cross-sectional studies can identify associations between risk factors and the outcome of interest, but they cannot identify a lack of association. Failure to find an association, for instance, may be a consequence of lack of variation in the predictor across the sampled farms, particularly when small samples are used. Further research is needed to confirm lack of association between leg problems and risk factors identified in other regions (e.g., other work has found an association between deep bedding and decreased lameness, although this association was not confirmed in the current study). New risk factors might emerge as China's dairy industry grows and facility design and management practices continue to change. For example, overstocking stalls has been described as a risk factor for lameness and hock injuries (Leonard et al., 1996; Barrientos et al., 2013); the lack of association in the current study is likely due to good management practices on the farms evaluated (stocking density was lower than $110 \%$ on all but 1 farm).

Although small herds are still common in China (Fuller et al., 2006; Ma et al., 2012), the current study targeted large freestall herds, as the proportion of cows housed in this type of facility is expected to increase. Changes in management and housing practices are likely to result in a range of challenges for the Chinese dairy industry. The results of current study illustrate the value of benchmarking studies in documenting success and challenges across a range of farms within a region that share similar constraints. This type of study can be used to identify emerging risk factors and to illustrate the levels of success that some farms are able to achieve (e.g., on one farm the prevalence of hock regions was only 6 versus $95 \%$ on the worst farm in this sample). 
The current study describes a sample of convenience. Farm selection was at the discretion of the sales representatives and distributors, and farmers' consent was required, so a degree of selection bias was expected. However, the associations identified in this study were in agreement with the causal diagrams derived from the existing literature and we suggest that our findings provide valid, if preliminary, insights into risk factors for lameness and hock injuries in China's dairy industry.

Similarly to previous studies (Espejo and Endres, 2007; Fulwider et al., 2007; von Keyserlingk et al., 2012), our assessment targeted high-producing cows. This is the cohort at highest risk for new cases of lameness and hock injuries, because it is composed mostly of multiparous cows in early or mid lactation, factors associated with these ailments (Offer et al., 2000; Weary and Taszkun, 2000; Chapinal et al., 2010). This sampling strategy may overestimate the overall herd prevalence of leg problems to some extent, assuming that some cases might resolve as lactation progresses if properly treated. However, leg problems are usually long-term events and the lack of homogeneity of most high-producing groups (some included primiparous cows and a wide range of DIM) might have helped reduce the bias. This target sample provided advantages in estimating risk factors. High-producing cows are the cohort in which the effects of inappropriate facility design and management are more likely to surface and, therefore, the cohort where the strongest association between risk factors and leg problems are likely to be found. The high-producing group may, thus, serve as sentinels for the detection of risk factors for leg problems elsewhere on the farm. Furthermore, high-producing cows represent the group of animals with the greatest economic value on a dairy farm.

In agreement with similar on-farm lameness surveys (Espejo and Endres, 2007; Dippel et al., 2009; Chapinal et al., 2013), we defined lameness based on gait rather than hoof health (Somers et al., 2003; Barker et al., 2009; Cramer et al., 2009). Although good correlation exists between certain lesions, such as sole ulcers and gait impairment (Flower and Weary, 2006; Chapinal et al., 2009), not all hoof lesions result in gait alteration, and not all cases of lameness are associated with a visible hoof lesion (Manske et al., 2002). Gait can be assessed daily on farm as cows walk from the pen to the milking parlor, whereas hoof trimming is required to assess lesions. We suggest that the prevalence of animals with impaired gait is a better parameter than prevalence of hoof lesions to study the effect of herdlevel factors on lameness, and is a better indicator to evaluate the application of strategic prevention plans.

Due to practical limitations, we assessed only 1 hock per animal, potentially underestimating of the preva- lence of hock injuries. However, Potterton et al. (2011) reported that an animal with a given hair loss score on one limb was likely to be assigned the same score for the contralateral limb, and that only a small proportion of animals showed large disparities between limbs $(<9$ and $<2 \%$ for difference of 2 and 3 scores, respectively, on a 4 -point scale).

\section{CONCLUSIONS}

The prevalence of lameness and hock injuries in China were comparable with that of different regions of North America. The prevalence of lameness decreased with herd size and increased with barn age. Considering the complex, multifactorial nature of lameness, these associations are likely due to management and facility design in larger (e.g., more professionalized lameness management) and older farms (e.g., poorer floor quality and stall design). The prevalence of hock injuries also increased with barn age and decreased with deep bedding, reconfirming previous findings showing that ample bedding is key to preventing hock injuries in freestalls.

\section{ACKNOWLEDGMENTS}

We extend special thanks to Mercedes Vazquez-Anon and Geoffrey Zanton (Novus International Inc., St. Charles, MO) for their technical and financial support. Bian Sibei, Cui Chuntao, and Yu Lei [Novus International Trading (Shanghai) Co., Shanghai, China] are thanked for their role in introducing us to the dairies. The UBC Animal Welfare Program is funded through the Natural Sciences and Engineering Research Council of Canada (NSERC, Ottawa, ON, Canada) Industrial Research Chair program, with industry contributions from the Dairy Farmers of Canada (Ottawa, ON, Canada), Westgen Endowment Fund (Milner, BC, Canada), Zoetis (Kirkland, QC, Canada), BC Cattle Industry Development Fund (Kamloops, BC, Canada), the BC Dairy Association (Burnaby, BC, Canada), and Alberta Milk (Edmonton, AB, Canada).

\section{REFERENCES}

Alban, L. 1995. Lameness in Danish dairy cows: Frequency and possible risk factors. Prev. Vet. Med. 22:213-225.

Arkins, S. 1981. Lameness in dairy cows. Ir. Vet. J. 35:135-140.

Barker, Z. E., J. R. Amory, J. L. Wright, S. A. Mason, R. W. Blowey, and L. E. Green. 2009. Risk factors for the increased rates of sole ulcers, white line disease, and digital dermatitis in dairy cattle from twenty-seven farms in England and Wales. J. Dairy Sci. 92:1971-1978.

Barker, Z. E., K. A. Leach, H. R. Whay, N. J. Bell, and D. C. J. Main. 2010. Assessment of lameness prevalence and associated risk factors in dairy herds in England and Wales. J. Dairy Sci. 93:932-941. 
Barrientos, A. K., N. Chapinal, D. M. Weary, E. Galo, and M. A. G. von Keyserlingk. 2013. Herd-level risk factors for hock injuries in freestall-housed dairy cows in the northeastern United States and California. J. Dairy Sci. 96:3758-3765.

Brenninkmeyer, C., S. Dippel, J. Brinkmann, S. March, C. Winckler, and U. Knierim. 2013. Hock lesion epidemiology in cubicle housed dairy cows across two breeds, farming systems and countries. Prev. Vet. Med. 109:236-245.

CCAC (Canadian Council on Animal Care). 2009. CCAC Guidelines On: The Care and Use of Farm Animals in Research, Teaching and Testing. CCAC, Ottawa, ON, Canada.

Chapinal, N., A. K. Barrientos, M. A. G. von Keyserlingk, E. Galo, and D. M. Weary. 2013. Herd-level risk factors for lameness in freestall farms in the northeastern United States and California. J. Dairy Sci. 96:318-328.

Chapinal, N., A. M. de Passillé, D. M. Weary, M. A. G. von Keyserlingk, and J. Rushen. 2009. Using gait score, walking speed, and lying behavior to detect hoof lesions in dairy cows. J. Dairy Sci. 92:4365-4374

Chapinal, N., C. Goldhawk, A. M. de Passillé, M. A. G. von Keyserlingk, D. M. Weary, and J. Rushen. 2010. Overnight access to pasture does not reduce milk production or feed intake in dairy cattle. Livest. Sci. 129:104-110.

Cook, N. B., and K. V. Nordlund. 2009. The influence of the environment on dairy cow behavior, claw health and herd lameness dynamics. Vet. J. 179:360-369.

Cramer, G., K. D. Lissemore, C. L. Guard, K. E. Leslie, and D. F. Kelton. 2009. Herd-level risk factors for seven different foot lesions in Ontario Holstein cattle housed in tie stalls or free stalls. J. Dairy Sci. 92:1404-1411.

DAC (Dairy Association of China). 2008. The improvement on population genetics in Chinese dairy cattle (2008-2020). China Dairy Cattle 4:4-7. (In Chinese).

Dippel, S., M. Dolezal, C. Brenninkmeyer, J. Brinkmann, S. March, U. Knierim, and C. Winckler. 2009. Risk factors for lameness in freestall-housed dairy cows across two breeds, farming systems, and countries. J. Dairy Sci. 92:5476-5486.

Dohoo, I., W. Martin, and H. Stryhn. 2009. Veterinary Epidemiologic Research. 2nd ed. VER Inc., Charlottetown, Prince Edward Island, Canada.

Espejo, L. A., and M. I. Endres. 2007. Herd-level risk factors for lameness in high-producing Holstein cows housed in freestall barns. J Dairy Sci. 90:306-314.

Espejo, L. A., M. I. Endres, and J. A. Salfer. 2006. Prevalence of lameness in high-producing Holstein cows housed in freestall barns in Minnesota. J. Dairy Sci. 89:3052-3058.

Flower, F. C., and D. M. Weary. 2006. Effect of hoof pathologies on subjective assessments of dairy cow gait. J. Dairy Sci. 89:139-146.

Fuller, F., J. Huang, H. Ma, and S. Rozelle. 2006. Got milk? The rapid rise of China's dairy sector and its future prospects. Food Policy $31: 201-215$.

Fulwider, W. K., T. Grandin, D. J. Garrick, T. E. Engle, W. D. Lamm, N. L. Dalsted, and B. E. Rollin. 2007. Influence of free-stall base on tarsal joint lesions and hygiene in dairy cows. J. Dairy Sci. 90:3559-3566.

Haskell, M. J., L. J. Rennie, V. A. Bowell, M. J. Bell, and A. B. Lawrence. 2006. Housing system, milk production, and zero-grazing effects on lameness and leg injury in dairy cows. J. Dairy Sci. 89:4259-4266.

Husfeldt, A. W., and M. I. Endres. 2012. Association between stall surface and some animal welfare measurements in freestall dairy herds using recycled manure solids for bedding. J. Dairy Sci. 95:5626-5634.

Kielland, C., L. E. Ruud, A. J. Zanella, and O. Østerås. 2009. Prevalence and risk factors for skin lesions on legs of dairy cattle housed in freestalls in Norway. J. Dairy Sci. 92:5487-5496.

Leonard, F. C., J. M. O'Connell, and K. J. O'Farrell. 1996. Effect of overcrowding on claw health in first-calved Friesian heifers. $\mathrm{Br}$. Vet. J. 152:459-472.

Lombard, J. E., C. B. Tucker, M. A. G. von Keyserlingk, C. A. Kopral, and D. M. Weary. 2010. Associations between cow hygiene, hock injuries, and free stall usage on US dairy farms. J. Dairy Sci. 93:4668-4676

Ma, H., L. Oxley, A. Rae, C. Fan, J. Huang, and S. Rozelle. 2012. The evolution of productivity performance on China's dairy farms in the new millennium. J. Dairy Sci. 95:7074-7085.

Manske, T., J. Hultgren, and C. Bergsten. 2002. Prevalence and interrelationships of hoof lesions and lameness in Swedish dairy cows. Prev. Vet. Med. 54:247-263.

Norring, M., E. Manninen, A. M. de Passillé, J. Rushen, L. Munksgaard, and H. Saloniemi. 2008. Effects of sand and straw bedding on the lying behavior, cleanliness, and hoof and hock injuries of dairy cows. J. Dairy Sci. 91:570-576.

Offer, J. E., D. McNulty, and D. N. Logue. 2000. Observations of lameness, hoof conformation and development of lesions in dairy cattle over four lactations. Vet. Rec. 147:105-109.

Potterton, S. L., M. J. Green, K. M. Millar, C. J. Brignell, J. Harris, H. R. Whay, and J. N. Huxley. 2011. Prevalence and characterization of, and producers' attitudes towards, hock lesions in UK dairy cattle. Vet. Rec. 169:634.

Rutherford, K. M. D., F. M. Langford, M. C. Jack, L. Sherwood, A. B. Lawrence, and M. J. Haskell. 2008. Hock injury prevalence and associated risk factors on organic and nonorganic dairy farms in the United Kingdom. J. Dairy Sci. 91:2265-2274.

Somers, J. G., K. Frankena, E. N. Noordhuizen-Stassen, and J. H. Metz. 2003. Prevalence of claw disorders in Dutch dairy cows exposed to several floor systems. J. Dairy Sci. 86:2082-2093.

van Gastelen, S., B. Westerlaan, D. J. Houwers, and F. J. C. M. van Eerdenburg. 2011. A study on cow comfort and risk for lameness and mastitis in relation to different types of bedding materials. J. Dairy Sci. 94:4878-4888.

von Keyserlingk, M. A. G., A. K. Barrientos, K. Ito, E. Galo, and D. M. Weary. 2012. Benchmarking cow comfort on North American freestall dairies: Lameness, leg injuries, lying time, facility design, and management for high-producing Holstein dairy cows. J. Dairy Sci. 95:7399-7408

Weary, D. M., and I. Taszkun. 2000. Hock lesions and free-stall design. J. Dairy Sci. 83:697-702.

Whitaker, D. A., J. M. Kelly, and S. Smith. 2000. Disposal and disease rates in 340 British dairy herds. Vet. Rec. 146:363-367.

Wu, J., J. S. Brickell, L. G. Yang, Z. Cheng, H. Q. Zhao, D. C. Wathes, and S. J. Zhang. 2012. Reproductive performance and survival of Chinese Holstein dairy cows. Anim. Prod. Sci. 52:11-19.

Zdanowicz, M., J. A. Shelford, C. B. Tucker, D. M. Weary, and M. A. G. von Keyserlingk. 2004. Bacterial populations on teat ends of dairy cows housed in free stalls and bedded with either sand or sawdust. J. Dairy Sci. 87:1694-1701.

Zhou, Z.-Y., W.-M. Tian, and J.-L. Zhou. 2002. The emerging dairy economy in China: Production, consumption and trade prospects. Australas. Agribus. Rev. 10:Paper 8. 